\title{
Pengaruh Konsentrasi Garam Dan Lama Fermentasi Terhadap Karakteristik Pikel Cabai Pimiento (Capsicum chinense)
}

\section{Effects concentration of salt and long fermentation against characterist pickle pimiento (capsicum chinense)}

\author{
Amelia Mardhatillah $^{1}$, I Gusti Ayu Ekawati ${ }^{*}$, Ni Made Indri Hapsari Arihantana ${ }^{1}$ \\ Program Studi Teknologi Pangan, Fakultas Teknologi Pertanian, \\ Universitas Udayana, Kampus Bukit Jimbaran, Badung-Bali
}

Penulis korespondensi: IG.A.Ekawati, Email: ayuekawati@unud.ac.id

\begin{abstract}
The research was conducted for the purpose of know the effect concentration of salt and fermentation time against the characteristic of pimiento pickle. The design used in this research was completely randomized design (RAL) factorials pattern, consisting of two factors . The first was the concentration of salt with concentration of $3 \%, 6 \%$, and $9 \%$. The second factor was time consisting of two and three weeks. The whole treatment repeated three times to obtain 18 unit experiment .The data was analyzed with duncan test. The results of the study showed that the treatment of salt with 6 $\%$ concentration with 3 weeks fermentation was capable of producing pimento pickle with the best characteristic total criteria of lactic acid bacteria $4.8 \times 10^{-6} \mathrm{CFU} / \mathrm{ml}, \mathrm{pH} 4.89$, total acid $0.576 \%$ and total dissolved solids $9.67^{0}$ Brix.
\end{abstract}

Keywords : lactic acid, pimiento chili, fermentation

\section{PENDAHULUAN}

Masyarakat pada umumnya hanya mengenal beberapa jenis cabai saja, yakni cabai besar, cabai keriting, cabai rawit dan paprika (Nurfalach, 2010). Akan tetapi ada satu jenis cabai yang belum mendapat perhatian yaitu cabai pimiento, informasi yang terbatas mengenai cabai pimiento menyebabkan hanya sedikit masyarakat yang mengetahui jenis cabai ini. Cabai pimiento memiliki karakteristik rasa yang berbeda dengan cabai pada umumnya yaitu tidak begitu pedas dan juga memiliki rasa manis namun cabai pimiento memiliki sifat yang mudah rusak. Sifat mudah rusak ini dipengaruhi oleh kadar air dalam cabai yang sangat tinggi sekitar 90\%. Kandungan air yang sangat tinggi menyebabkan kerusakan cabai pimiento pada saat musim panen raya. Hal ini dikarenakan hasil panen yang melimpah sedangkan permintaan pasar menurun, sehingga menyebabkan pembusukan (Belitz. 2009). Oleh karena itu perlu dilakukan cara untuk menanggulangi pada saat panen raya dengan cara mengolahnya.Salah satu cara pengolahan yang dapat dilakukan pada cabai adalah mengolahnya menjadi pikel, sehingga dapat meningkatkan umur simpan dari cabai pimiento tersebut. Menurut Rukmana (1996), 
pikel adalah makanan berkalori rendah, sehingga baik untuk kesehatan, yang diproses melalui fermentasi.

Pada umumnya proses fermentasi pikel berlangsung selama 2 sampai 3 minggu dengan suhu $21^{\circ} \mathrm{C}$ sampai dengan $24^{\circ} \mathrm{C}$ (Anon., 2009 $9^{\mathrm{a}}$. Proses fermentasi pikel dipengaruhi oleh berbagai faktor, seperti kondisi anaerobik, konsentrasi garam, suhu, dan adanya bakteri asam laktat (Buckle et al. 1995). Selanjutnya terjadi fermentasi gula oleh bakteri asam laktat yang menghasilkan asam laktat (Astuti., 2006). Menurut Buckle et al., (1987) pada proses fermentasi pikel penambahan garam 3\% sampai $10 \%$ dalam kondisi anaerob akan merangsang pertumbuhan BAL, jika konsentrasi garam yang digunakan untuk proses fermentasi terlalu rendah, maka terjadi pelunakan jaringan buah dan sayur, apabila jumlah garam yang terlalu banyak akan menunda fermentasi alami, yang menyebabkan warna produk menjadi gelap, oleh karena itu tujuan dari penelitian ini untuk mengetahui pengaruh konsentrasi garam dan lama fermentasi terhadap karakteristik pikel cabai pimiento (Capsicum chinense).

\section{METODE PENELITIAN}

\section{Tempat dan Waktu Penelitian}

Penelitian ini dilakukan di laboratorium Pengolahan Pangan, Analisis Pangan dan Mikrobiologi Pangan Fakultas Teknologi Pertanian, Gedung Agrokomplek Universitas Udayana, Jalan P. B. Sudirman Denpasar Bali.
Penelitian ini berlangsung selama 3 bulan dari bulan Februari hingga bulan April 2017.

\section{Bahan dan Alat}

Bahan yang digunakan dalam penelitian ini adalah cabai pimiento berwarna orange yang diperoleh dari daerah Bedugul, Kabupaten Tabanan Provinsi Bali, garam dapur, gula (merk gulaku), garam fisiologis $0,85 \%$, phenolptalin, $\mathrm{NaOH} 0,1 \mathrm{~N}$, aquades, alkohol, dan MRS (Media de mann Regosa and Sharpe) agar. Adapun alat yang digunakan dalam penelitian ini, antara lain: kompor, panci, autoclave, laminar air flow kabinet, micro pipet, vortex, tabung reaksi, rak tabung, termometer, jar, cawan petri, $\mathrm{pH}$ meter, gelas beker, gelas ukur, labu erlenmeyer, pipet tetes, timbangan analitik, refraktometer, pinset, bunsen, inkubator, buret, sarung tangan, tissu, alluminium foil, plastik wrap.

\section{Rancangan Penelitian}

Rancangan percobaan yang digunakan dalam penelitian ini adalah rancangan acak lengkap (RAL) pola faktorial dengan 2 faktor perlakuan yaitu perlakuan konsentrasi garam (G) yang terdiri dari tiga level, dan lama fermentsi (W) yang terdiri dari 2 level yaitu G1 (3\%), G2 (6\%), G3 (9\%) dan W1 (2 Minggu), W2 (3Minggu). Masing-masing perlakuan diulang sebanyak 3 kali, sehingga di peroleh 18 unit percobaan. Data yang diperoleh dianalisis dengan sidik ragam, jika perlakuan berpengaruh terhadap variabel yang diamati, dilanjutkan dengan uji jarak berganda atau perbandingan berganda Duncan (Steel 
dan Torrie,1993). Kombinasi perlakuan dalam

pengolahan pikel cabai pimiento dapat dilihat

pada Tabel 1.

Tabel 1. Kombinasi Perlakuan Pikel Cabai Pimiento

\begin{tabular}{ccc}
\hline & \multicolumn{2}{c}{ Perlakuan } \\
\cline { 2 - 3 } Konsentrasi Garam & W1 & W2 \\
\hline G1 & G1W1 & G1W2 \\
G2 & G2W1 & G2W2 \\
G3 & G3W1 & G3W2
\end{tabular}

\section{Pelaksanaan Penelitian}

Cabai pimiento sebelum diolah disortir terlebih dahulu dengan tujuan untuk memilih kualitas cabai dengan mutu yang terbaik, selanjutnya cabai dibersihkan dengan menghilangkan biji cabai dan benda asing yang dapat mengganggu proses pengolahan, cabai ditimbang $40 \mathrm{~g}$ dan dicuci, ditiriskan lalu di potong memanjang dengan ukuran $6 \mathrm{~cm}$ selanjutnya diblanching selama 5 menit dengan suhu $95^{\circ} \mathrm{C}, \quad$ kemudian cabai dimasukkan kedalam jar yang berisi $100 \mathrm{ml}$ larutan garam konsentrasi sesuai perlakuan yaitu $(3 \%, 6 \%$, dan $9 \%)$ selanjutnya sampel yang sudah dalam kemasan jar dipasteurisasi selama 15 menit dengan suhu $80^{\circ} \mathrm{C}$ dan difermentasi sesuai perlakuan selama 2 dan 3 minggu (Djubaedah et al., 2004 yang dimodifikasi).

\section{Variabel yang Diamati}

Pengamatan total bakteri asam laktat (BAL) dengan metode tuang, (Fardiaz,1993), penentuan pH (Sudarmadji,et al.,1989) dengan menggunakan $\mathrm{pH}$ meter, penentuan total asam dengan metode titrasi (Sudarmadji,et al.,1997) penentuan total padatan dengan menggunakan metode alat refraktometer (Adirahmanto,2013) dan evaluasi sensori menggunakan 15 orang panelis semi terlatih (Lee et al., 2013).

\section{HASIL DAN PEMBAHASAN}

\section{Total Bakteri Asam Laktat (BAL)}

Nilai rata - rata pada total bakteri asam laktat (BAL) dapat dilihat pada Tabel 2. Hasil Sidik ragam menunjukkan bahwa interaksi antara perlakuan lama fermentasi dengan konsentrasi garam pada pengolahan pikel cabai pimiento berpengaruh nyata $(\mathrm{P}<0,05)$ terhadap pertumbuhan BAL. pada Tabel 2 menunjukkan bahwa total bakteri asam laktat tertinggi diperoleh pada (G2W2), total koloni $4.8 \times 10^{6} \mathrm{CFU} / \mathrm{ml}$ dan terendah di peroleh pada perlakuan (G3W2) dengan total koloni $1.6 \times 10^{6} \mathrm{CFU} / \mathrm{ml}$. Perlakuan konsentrasi garam 6\% merupakan konsentrasi garam yang dapat untuk pertumbuhan BAL sedangkan 3 minggu merupakan waktu lama fermentasi untuk pertumbuhan BAL pada pikel cabai 
pimiento. Kuwaki et al., (2012) menyatakan, variasi garam yang ditambahkan masih dalam range konsentrasi yang cocok untuk pertumbuhan bakteri asam laktat. Garam berfungsi sebagai media pertumbuhan dan nutrisi bagi pertumbuhan asam laktat. Diketahui bahwa bakteri asam laktat homofermentatif mampu memetabolisme gula sederhana menjadi asam laktat secara lebih dominan (85\%) bila dibanding dengan bakteri asam laktat heterofermentatif (Axelsson,
1998), sedangkan total bakteri asam laktat terendah pada (G3W2), hal ini di sebabkan lama fermentasi 3 minggu pada konsentrasi garam 9\% terjadi karena semakin tinggi penambahan konsentrasi garam menyebabkan ketidakseimbangan tekanan osmosis pada bahan, sehingga pertumbuhan mikroba semakin lambat saat proses fermentasi mikroba tidak dapat tumbuh dan hidup (Apriantono, 2004.)

Tabel 2. Nilai rata - rata Total Bakteri Asam Laktat (BAL)

\begin{tabular}{ccc}
\hline \multirow{2}{*}{ Konsentrasi Garam $(\mathrm{G})$} & \multicolumn{2}{c}{ Lama Waktu Fermentasi (W) } \\
\cline { 2 - 3 } & 2 Minggu (W1) & 3 Minggu (W2) \\
\hline $3 \%(\mathrm{G} 1)$ & $4,5 \times 10^{6} \mathrm{~A}$ & $3,7 \times 10^{6} \mathrm{~A}$ \\
$6 \%(\mathrm{G} 2)$ & $\mathrm{a}$ & $\mathrm{a}$ \\
& $3,5 \times 10^{6} \mathrm{~A}$ & $4,8 \times 10^{6} \mathrm{~A}$ \\
$9 \%(\mathrm{G} 3)$ & $\mathrm{a}$ & $\mathrm{a}$ \\
& $4,3 \times 10^{6} \mathrm{~A}$ & $1,6 \times 10^{6} \mathrm{~B}$ \\
& $\mathrm{a}$ & $\mathrm{b}$ \\
\hline
\end{tabular}

Keterangan: Nilai rata-rata yang diikuti huruf yang sama pada kolom yang sama menunjukkan berbeda tidak nyata $(\mathrm{p}>0,05)$.

Nilai rata-rata yang diikuti huruf yang sama pada baris yang sama menunjukkan berbeda tidak nyata $(\mathrm{p}>0,05)$.

Tabel 3. Nilai rata - rata pH pikel cabai pimiento.

\begin{tabular}{ccc}
\hline \multirow{2}{*}{ Konsentrasi Garam $(\mathrm{G})$} & \multicolumn{2}{c}{ Lama Waktu Fermentasi (W) } \\
\cline { 2 - 3 } & 2 Minggu (W1) & 3 Minggu (W2) \\
\hline $3 \%(\mathrm{G} 1)$ & $4,68 \mathrm{AB}$ & $4,60 \mathrm{AB}$ \\
& $\mathrm{ab}$ & $\mathrm{ab}$ \\
$6 \%(\mathrm{G} 2)$ & $4,74 \mathrm{AB}$ & $4,89 \mathrm{~A}$ \\
& $\mathrm{ab}$ & $\mathrm{a}$ \\
$9 \%(\mathrm{G} 3)$ & $4,71 \mathrm{AB}$ & $4,56 \mathrm{~B}$ \\
& $\mathrm{ab}$ & $\mathrm{b}$ \\
\hline
\end{tabular}

Keterangan: Nilai rata-rata yang diikuti huruf yang sama pada kolom yang sama menunjukkan berbeda tidak nyata $(\mathrm{p}>0,05)$

Nilai rata-rata yang diikuti huruf yang sama pada baris yang sama menunjukkan berbeda tidak nyata $(\mathrm{p}>0,05)$. 


\section{Penentuan pH}

Nilai rata - rata $\mathrm{pH}$ pada pengolahan pikel cabai pimiento dapat dilihat pada Tabel 3. Analisis ragam menunjukkan bahwa interaksi antara perlakuan lama fermentasi dengan konsentrasi garam berpengaruh sangat nyata $(\mathrm{P}<0,01)$ terhadap $\mathrm{pH}$ pikel cabai pimiento. Pada Tabel 3 menunjukkan bahwa nilai rata - rata tertinggi diperoleh pada perlakuan G2W2 yaitu 4.89 dan nilai rata rata terendah diperoleh pada perlakuan G3W2 yaitu 4.56. Hal ini disebabkan selama proses fermentasi BAL akan memfermentasi karbohidrat yang ada hingga terbentuk asam laktat, maka terjadi penurunan nilai $\mathrm{pH}$ dan peningkatan keasaman (Djafar dan Rahayu. 2006). Menurut Axelsson, (1998) hal ini karena asam yang terbentuk selama fermentasi dominannya adalah asam laktat yang tergolong asam lemah sehingga tidak secara drastis memberikan penurunan $\mathrm{pH}$ yang besar. Berdasarkan pada hasil penelitian pembuatan pikel sawi (Fathonah,S. 2009.) konsentrasi garam berpengaruh terhadap $\mathrm{pH}$. Maka asam laktat yang dihasilkan semakin banyak sehingga semakin menurunkan $\mathrm{pH}$.

\section{Total Asam}

Nilai rata-rata hasil analisis ragam menunjukkan interaksi antara perlakuan lama fermentasi dan konsentrasi garam pada fermentasi pikel cabai pimiento berpengaruh sangat nyata $(\mathrm{P}<0,01)$. Nilai rata-rata total asam pikel cabai pimiento dapat dilihat pada Tabel 4. Total asam pikel cabai pimiento berkisar antara 0,2941\% hingga 0,5876\%. Nilai rata - rata tertinggi diperoleh pada perlakuan G2W2 yaitu $0,5876 \%$ dan nilai rata - rata terendah diperoleh pada perlakuan G3W2 yaitu 0,2941\% (Tabel 4). Waktu lama fermentasi dan konsentrasi garam berkaitan dengan nilai $\mathrm{pH}$ dan jumlah total asam yang dihasilkan pikel cabai pimiento yaitu semakin tinggi nilai total asam maka semakin rendah nilai $\mathrm{pH}$ (asam).

Peningkatan total asam terjadi karena adanya aktivitas bakteri pembentuk asam laktat yang mengubah glukosa menjadi asam laktat dalam kondisi anaerob. Penambahan garam dengan konsentrasi yang sesuai akan mendorong terbentuknya bakteri asam laktat dan menekan pertumbuhan bakteri yang tidak diinginkan (Buckle et al. 1985). Total asam dalam acar selama 2 minggu meningkat 0,5 $1 \%$, dan secara bertahap akan berkurang karena dikonsumsi oleh bakteri (Munajini 1988). Kandungan asam akan menurun bila fermentasi berlangsung lebih cepat atau kurang dari 14 hari. Pada kondisi asam yang rendah, bakteri yang resisten terhadap kandungan asam rendah dan suhu tinggi akan aktif kembali, karena pada kondisi ini beberapa jenis bakteri akan memproduksi asam dari gula sehingga keasaman meningkat (Djunjung dan Ansory, 1992).

\section{Total Padatan Terlarut (TPT)}

Nilai rata - rata hasil total padatan terlarut dapat dilihat pada Tabel 5. Hasil analisis ragam menunjukkan bahwa interaksi 
perlakuan lama fermentasi dengan konsentrasi garam berpengaruh sangat nyata $(\mathrm{P}<0,01)$ terhadap total padatan terlarut pikel cabai pimiento. Pada Tabel 5. Menunjukkan bahwa nilai rata - rata tertinggi diperoleh pada perlakuan G2W2 yaitu $9,67^{\circ}$ Brix dan nilai rata - rata terendah diperoleh pada perlakuan G3W2 yaitu $5,33^{\circ}$ Brix. Hal ini diesebabkan karena, selama berlangsungnya proses fermentasi, bakteri asam laktat menghasilkan metabolit berupa asam laktat yang mendegradasi menjadi sukrosa sehingga menyebabkan TPT meningkat. Metabolit tersebut akan tersekresikan keluar sel dan akan terakumulasi dalam cairan fermentasi. Sisa hasil total gula, asam laktat, dan asam organik yang terbentuk terhitung sebagai total padatan terlarut. Komponen padatan terlarut terdiri dari total gula, pigmen, asam-asam organik dan protein. Asam laktat termasuk asam organik yamg merupakan salah satu jenis total padatan terlarut selain gula, pigmen, dan vitamin (Fardiaz, 1993). Kenaikan nilai TPT disebabkan oleh degradasi komponen dinding sel seperti pektin, selulosa, hemiselulosa dan lignin menjadi komponen yang lebih sederhana yang dapat larut dalam air (Sunarmani et al., 1996).

Tabel 4. Nilai rata - rata total asam pikel cabai pimiento

\begin{tabular}{ccc}
\hline \multirow{2}{*}{ Konsentrasi Garam $(\mathrm{G})$} & \multicolumn{2}{c}{ Lama Waktu Fermentasi (W) } \\
\cline { 2 - 3 } & 2 Minggu (W1) & 3 Minggu (W2) \\
\hline $3 \%(\mathrm{G} 1)$ & $0,4696 \% \mathrm{~B}$ & $0,4701 \% \mathrm{~B}$ \\
& $\mathrm{~b}$ & $\mathrm{~b}$ \\
$6 \%(\mathrm{G} 2)$ & $0,3920 \% \mathrm{C}$ & $0,5876 \% \mathrm{~A}$ \\
& $\mathrm{c}$ & $\mathrm{a}$ \\
$9 \%(\mathrm{G} 3)$ & $0,3520 \% \mathrm{D}$ & $0,2941 \% \mathrm{E}$ \\
& $\mathrm{d}$ & $\mathrm{e}$ \\
\hline
\end{tabular}

Keterangan: Nilai rata-rata yang diikuti huruf yang sama pada kolom yang sama menunjukkan berbeda tidak nyata $(\mathrm{p}>0,05)$.

Nilai rata-rata yang diikuti huruf yang sama pada baris yang sama menunjukkan berbeda tidak nyata $(\mathrm{p}>0,05)$.

Tabel 5. Nilai rata - rata total padatan terlarut (TPT) pikel cabai pimiento.

\begin{tabular}{ccc}
\hline \multirow{2}{*}{ Konsentrasi Garam $(\mathrm{G})$} & \multicolumn{2}{c}{ Lama Waktu Fermentasi (W) } \\
\cline { 2 - 3 } & 2 Minggu $(\mathrm{W} 1)$ & 3 Minggu (W2) \\
\hline \multirow{2}{*}{$3 \%(\mathrm{G} 1)$} & $9.33 \mathrm{AB}$ & $8.33 \mathrm{BC}$ \\
& $\mathrm{ab}$ & $\mathrm{bc}$ \\
$6 \%(\mathrm{G} 2)$ & $7.33 \mathrm{CD}$ & $9.67 \mathrm{~A}$ \\
& $\mathrm{~cd}$ & $\mathrm{a}$ \\
$9 \%(\mathrm{G} 3)$ & $6.67 \mathrm{D}$ & $5.33 \mathrm{E}$ \\
\end{tabular}

Keterangan: Nilai rata-rata yang diikuti huruf yang sama pada kolom yang sama menunjukkan berbeda tidak nyata $(\mathrm{p}>0,05)$.

Nilai rata-rata yang diikuti huruf yang sama pada baris yang sama menunjukkan berbeda tidak nyata $(\mathrm{p}>0,05)$. 


\section{Evaluasi Sensoris}

Evaluasi sensoris pikel cabai pimiento dilakukan dengan uji tingkat kesukaan (hedonik) terhadap warna, tekstur, aroma, rasa, dan penerimaan keseluruhan, serta uji skoring terhadap tekstur dan rasa. Nilai ratarata hasil analisis warna, tekstur, aroma, rasa, dan penerimaan keseluruhan pikel cabai pimiento dapat dilihat pada Tabel 6 .

\section{Warna}

Hasil analisis ragam uji hedonik pikel cabai pimiento menunjukkan perlakuan lama fermentasi dan konsentrasi garam berpengaruh nyata $(\mathrm{P}>0,05)$ terhadap warna yang dihasilkan dalam pengolahan pikel cabai pimiento, Tabel 6 menunjukkan nilai rata-rata kesukaan panelis terhadap warna berkisar antara 3.25 sampai dengan 5.50. Nilai terendah dihasilkan pada perlakuan (G3W1) yaitu dengan kriteria tidak suka, dan yang tertinggi dihasilkan pada perlakuan (G2W1) dengan kriteria sangat suka. Hal ini disebabkan tingkat kematangan cabai yang maksimal ditambah proses blansing pada saat pengolahan pikel cabai pimiento dapat menambah daya tarik panelis.

Tabel 6. Nilai rata - rata evaluasi sensoris hedonik dan skoring

\begin{tabular}{cccccccc}
\hline \multirow{2}{*}{ Perlakuan } & \multirow{2}{*}{ Warna } & \multicolumn{2}{c}{ Tekstur } & Aroma & \multicolumn{2}{c}{ Rasa } & $\begin{array}{c}\text { Penerimaan } \\
\text { Keseluruhan }\end{array}$ \\
\cline { 2 - 8 } & Hedonik & Hedonik & Skoring & Hedonik & Hedonik & Skoring & Hedonik \\
\hline G1W1 & $4.88 \mathrm{a}$ & $5.73 \mathrm{a}$ & $4.00 \mathrm{a}$ & $4.33 \mathrm{~d}$ & $4.33 \mathrm{~cd}$ & $3.47 \mathrm{c}$ & $5.60 \mathrm{a}$ \\
G2W1 & $5.50 \mathrm{a}$ & $5.00 \mathrm{ab}$ & $2.33 \mathrm{c}$ & $4.87 \mathrm{~cd}$ & $4.60 \mathrm{bcd}$ & $4.80 \mathrm{a}$ & $4.80 \mathrm{bc}$ \\
G3W1 & $3.25 \mathrm{~b}$ & $4.73 \mathrm{ab}$ & $2.60 \mathrm{c}$ & $5.00 \mathrm{bcd}$ & $4.80 \mathrm{abc}$ & $4.53 \mathrm{~b}$ & $5.47 \mathrm{ab}$ \\
G1W2 & $4.75 \mathrm{ab}$ & $4.40 \mathrm{bc}$ & $3.07 \mathrm{~b}$ & $5.27 \mathrm{abc}$ & $4.00 \mathrm{~d}$ & $4.00 \mathrm{~b}$ & $4.80 \mathrm{bc}$ \\
G2W2 & $4.63 \mathrm{ab}$ & $4.27 \mathrm{bc}$ & $3.67 \mathrm{a}$ & $5.67 \mathrm{ab}$ & $5.13 \mathrm{a}$ & $4.87 \mathrm{a}$ & $5.73 \mathrm{a}$ \\
G3W2 & $4.25 \mathrm{ab}$ & $3.67 \mathrm{c}$ & $1.67 \mathrm{c}$ & $5.80 \mathrm{a}$ & $5.07 \mathrm{ab}$ & $3.13 \mathrm{c}$ & $4.67 \mathrm{c}$ \\
\hline
\end{tabular}

Keterangan: Nilai rata - rata warna, tekstur, aroma, rasa dan penerimaan keseluruhan yang diikuti oleh huruf yang berbeda pada kolom dan baris yang sama menunujukkan perbedaan yang sangat nyata $(\mathrm{P}<0,01)$

\section{Tekstur}

Hasil analisis ragam uji hedonik pikel cabai pimento menunjukkan bahwa pengaruh lama fermentasi dan konsentrasi garam berpengaruh sangat nyata $(\mathrm{P}<0,02)$ terhadap tekstur pikel cabai pimento Tabel 6 menunjukkan bahwa nilai rata-rata tingkat kesukaan panelis terhadap tekstur pikel cabai pimento berkisar antara 3,67 sampai dengan 5,73. Nilai rata - rata tertinggi diperoleh pada perlakuan (G1W1), sedangkan nilai rata - rata terendah diperoleh pada perlakuan (G3W2) yaitu 3,67. Pada hasil analsis ragam uji skoring pikel cabai pimento menunjukkan bahwa pengaruh lama fermentasi dan konsentrasi garam pada pikel cabai pimento 
berpengaruh sangat nyata $(\mathrm{P}<0,00)$ terhadap tekstur pikel cabai pimiento. Tabel 6 menunjukkan bahwa nalai rata - rata skor tertinggi terhadap pikel cabai pimiento berkisar antara 1,67 sampai dengan 4,00, skor tertinggi diperoleh pada perlakuan (G1W1) yaitu 4,00 sedangkan nilai skor terendah diperoleh pada (G3W2) yaitu 1,67. Tekstur pikel cabai pimento dipengaruhi oleh adanya penggunaan konsentrasi garam pada pengolahan pikel cabai pimento. Menurut Lempsey (2004), cabai pimento memiliki kadar air yang tinggi sehingga menghasilkan pikel cabai pimento dengan kadar air tinggi yang dapat mempengaruhi tekstur pikel cabai pimento yang dihasilkan. Kadar air pada pikel cabai pimento yang tinggi menyebabkan tekstur pikel cabai pimento disukai oleh panelis.

\section{Aroma}

Hasil analisis ragam uji hedonik pada pikel cabai pimento menunjukkan bahwa lama fermentasi dan konsentrasi garam berpengaruh sangat nyata $(\mathrm{P}>0,05)$ terhadap aroma pikel cabai pimento. Tabel 6 menunjukkan bahwa nilai rata-rata tingkat kesukaan panelis terhadap aroma pikel cabai pimento berkisar antara 4,33 sampai dengan 5,80 . Nilai rata-rata tertinggi kesukaan panelis terhadap aroma pikel cabai pimento diperoleh pada perlakuan (G3W2) yaitu 5,80 (suka), sedangkan nilai rata-rata terendah diperoleh pada perlakuan (G1W1) yaitu 4,33 (biasa). Penerimaan panelis terhadap aroma pikel cabai pimento semakin meningkat dengan semakin lama proses fermentasi pada pikel.

\section{Rasa}

Hasil analisis ragam uji hedonik pikel cabai pimento menunjukkan bahwa pengaruh lama fermentasi dan konsentrasi garam tidak berpengaruh nyata $(\mathrm{P}>0,05)$ terhadap rasa pikel cabai pimento Tabel 6 menunjukkan bahwa nilai rata-rata tingkat kesukaan panelis terhadap rasa pikel cabai pimento berkisar antara 4,00 (agak suka) sampai dengan 5,13 (suka). Nilai rata - rata tertinggi diperoleh pada perlakuan (G2W2) yaitu 5,13 (suka), sedangkan nilai rata - rata terendah diperoleh pada perlakuan (G1W2) yaitu 4,00 (agak suka. Pada hasil analsis ragam uji skoring pikel cabai pimento menunjukkan bahwa pengaruh lama fermentasi dan konsentrasi garam pada pikel cabai pimento berpengaruh sangat nyata $(\mathrm{P}<0,01)$ terhadap rasa pikel cabai pimento. Tabel 6 menunjukkan bahwa nilai rata - rata skor terhadap rasa pikel cabai pimentoberkisar antara 3,13 sampai dengan 4,87. Nilai ratarata skor tertinggi diperoleh pada perlakuan (G2W2) yaitu 4,87 (sangat asam), sedangkan nilai rata - rata terendah diperoleh pada perlakuan (G3W2) yaitu 3,13 (agak asam).

\section{Penerimaan Keseluruhan}

Hasil analisis ragam uji hedonik pikel cabai pimento menunjukkan bahwa pengaruh lama fermentasi dan konsentrasi garam berpengaruh nyata $(\mathrm{P}<0,01) \quad$ terhadap penerimaan keseluruhan pikel cabai pimento Tabel 6 menunjukkan bahwa nilai rata-rata 
tingkat kesukaan panelis terhadap penerimaan keseluruhan pikel cabai pimento berkisar antara 4,67 (agak suka) sampai dengan 5,73 (suka). Nilai rata - rata tertinggi diperoleh pada perlakuan (G2W2) yaitu 5,73 (suka), sedangkan nilai rata - rata terendah diperoleh pada perlakuan (G3W2) yaitu 4,67 (agak suka). Secara keseluruhan panelis dalam memberikan penilaian terhadap pikel cabai pimento yang dihasilkan menunjukkan bahwa semua perlakuan dapat diterima oleh panelis.

\section{KESIMPULAN DAN SARAN}

\section{Kesimpulan}

Interaksi antara perlakukan konsentrasi garam dan lama fermentasi pada pikel cabai pimento berpengaruh terhadap total bakteri asam laktat, $\mathrm{pH}$, total asam, total padatan terlarut, dan evaluasi sensoris pada warna, tekstur, aroma, rasa, dan penerimaan keseluruhan.

Perlakuan $6 \%$ garam dengan lama fermentasi 3 minggu mampu menghasilkan pikel cabai pimento dengan karakteristik terbaik dengan kriteria total bakteri asam laktat $4.8 \times 10^{-6} \mathrm{CFU} /$ ml, $\mathrm{pH} 4.89$, total asam $0.576 \%$ dan total padatan terlarut $9.67^{0}$ Brix. Sifat sensoris yang diperoleh yaitu warna oranye (suka), tekstur keras (suka), aroma (suka), rasa asam (suka), dan penerimaan keseluruhan terhadap pikel cabai pimiento dengan perbandingan konsentrasi garam 6\% dan lama fermentasi 3 minggu sangat suka.

\section{Saran}

Berdasarkan hasil penelitian ini disarankan untuk :
1. Apabila membuat pikel cabai pimiento disarankan menggunakan perlakuan garam dengan konsentrasi 6\% dengan lama fermentasi 3 minggu.

2. Perlu dilakukan penelitian lebih lanjut mengenai daya simpan pikel cabai pimento.

\section{DAFTAR PUSTAKA}

Adirahmanto, K.A. 2013. Perubahan Kimia dan Lama Simpan Buah Salak Pondoh (Salacca edulis Reinw) dalam Penyimpanan Dinamis UdaraCO.Skripsi S1. Fakultas Pertanian Universitas Lampung. Bandar Lampung. Anonimus. 2009 a . Food Safety and Preservation: Low Salt Pickles. Oregon State University Extension Service. SP 50-533, Revised May 2009. $3 \mathrm{hlm}$.

Apriantono, 2004. Pengolahan Berbagai Makanan, Institut Pertanian Bogor, Bogor

Astuti, S.M. 2006. Teknik Pelaksanaan Percobaan Pengaruh Konsentrasi Garam dan Blanching Terhadap Mutu Acar Buncis. Buletin Teknik Pertanian 58-63.

Axelsson, L. 1998. Lactic Acis Bacteria : Classification and Physiology. Dalam Salminen, S dan A.Von Wright (ed), 1998. Lactic Acid Bacteria : Microbology and Functional Aspects. Marcel Dekker. Inc. New York

Belitz, H. D., Grosch, W., Schieberle, P. 2009. Food Chemistry. Edisi 4 Revisi. Springer Berlin Heidelberg. New York.

Buckle, K.A., Edward, G.H. Fleed and M. Watton. Penterjemah Hari Purnomo, 1987. Ilmu Pangan, Jakarta. UI Press. 89 hlm.

Buckle, 1995. Food Science, diterjemahkan oleh Hari Purnomo dan Adiono, UI Press, Jakarta

Djunjung dan Ansory. 1992. Teknologi Fermentasi Sayuran dan Buah-buahan. PAU Pangan dan Gizi, Institut Pertanian Bogor. hlm. 48-74

Djubaedah, E., Djumarwan., Enny Hawani Lubis., Tuty Hendraswaty. 2004. 
Pengaruh Konsentrasi Garam, Penambahan Jenis Asam Terhadap Mutu Lada Hijau Dalam Botol Selama Penyimpanan. Jurnal Teknol dan Industri Pangan, Vol. XV, No 3. Fakultas Teknik. Universitas Pasundan. Bandung.

Djaafar,T.F dan E.S Rahayu. 2006. Karakteristiki yogurt dengan inokulum Lactobacillus yang diisolasi dari makanan fermentasi traditional. Agros. 8(1) $73-80$.

Fardiaz, S. 1993. Mikrobiologi Pangan I. Jakarta. Gramedia

Fathonah,S. 2009. Penngaruh konsentrasi garam dan penambahan sumber karbohidrat terhadap mutu organoleptik produk sawi asin. Skripsi S1, Bogor : Jurusan Teknologi Pangan dan Gizi Fakultas Teknologi Pertanian IPB

Kuwaki, S., Nobuyoshi, N., Hidehiko, T., dan Kohji, I. 2012. Plant-based Paste Fermented by Lactic Acid Bacteria and Yeast : Functional Analysis and Possibility of Application to Functional Foods. Original Research Libertas Academica, Japan. Biochemistry Insights., 2012:5, 21-29.

Lee, L.S., J.H. Choi, N. Son, S.H. Kim, J.D. Park, D.J. Jang, Y. Jeong, H.J. Kim. 2013. Metabolomic Analysis of the Effect of Shade Treatment on the
Nutritional and Sensory Qualities of Green Tea. J. Agric. Food Chem. 61(2):332-338.

Munajini. 1988. Teknologi Pengawetan Pangan. UI Press, Jakarta. hlm. 341-348.

Nurfalach, D.R. 2010. Budidaya Tanaman Cabai Merah (Capsicuma Annum L.) Di UPTD Pembibitan Tanaman Hortikultura Desa Pakopen Kecamatan Bandungan Kabupaten Semarang. Tugas Akhir (TA) D3.Fakultas Pertaian Universitas Sebelas Maret. Surakarta.

Nurlaela, Ai.2003. Penyimpanan Buah Jambu Biji Jenis Bangkok Segar Pada Suhu Kamar Yang Telah Diradiasi Sinar Gamma (60Co). Skripsi. Departemen . Fisika. Institut Pertanian Bogor

Rukmana, R. 1996. Budidaya Mentimun Gherkin untuk Ekspor. No. 319, Tahun XX VII, Juni, 1996.

Sudarmadji, S., Haryono, B., dan Suhardi. 1989. Analisa Bahan Makanan dan Pertanian. Liberty. Yogyakarta.

Sunarmani et al. 1996. Pengaruh Komposisi Oksigen dan Karbondioksida Dalam Wadah Tertutup Terhadap Mutu dan Daya Simpan Nenas. Jakarta:J.Hort.5(5):80-93

Steel,R.G.D dan J.H.Torrie. 1993. Prinsip dan Proseduk Statistika. Terjemahan Bambang Sumantri. Gramedia. Jakarta 